\title{
Deformations striking parallel to glacier movement as a problem in reconstructing its direction
}

\author{
HANS-JÜRGEN STEPHAN
}

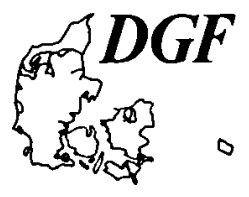

\begin{abstract}
Stephan, H.-J.: Deformations striking parallel to glacier movement as a problem in reconstructing its direction. Bull. geol. Soc. Denmark, vol. 34, 47-54, Copenhagen, May, 30th, 1985.

https://doi.org/10.37570/bgsd-1985-34-05

The structural analysis of glacigene deformations can lead to a wrong view on the movement of the in-land ice when deformations which strike parallel to the direction of glacier movement are interpreted as striking transverse. Parallel striking deformations are more frequent than it is often believed. They are found in push ridges at the lateral margins of ice lobes, but also in end moraines and below ground morai-nes. They seem to be especially frequent in a drumlinized landscape where they often occur together with structures striking oblique to the direction of the glacier movement. Several examples from Schleswig-Holstein are shortly described and discussed.
\end{abstract}

H.-J. Stephan, Geologisches Landesamt Schleswig-Holstein, Mercatorstr. 7, D 23 Kiel 1, Germany, Oc-tober, 8th, 1982.

\section{Introduction}

To reconstruct the direction of glacier flow in an old glacial landscape is a frequent aim of glacial geological investigations. The following methods are used: The morphological analysis; measuring of the strike of surface marks as striations and crescentic fractures or of forms at the lower surface of a till stratum as undulations, ribs, edges and wedges; fabric analysis in the ground moraine as measuring the orientation and the dip of long axes of elongated pebbles or grains or as analysing the joint system; at last structural analysis of glacigene deformations.

A few special morphological features, striations combined with crescentic fractures on stone pavements, also slickensides or ribs at the lower surface of a till stratum (Ehlers \& Stephan 1979) allow to determine directly the line or the direction of the glacier movement. Where they are lacking glacigene deformations are preferentially studied, and often it is thought that the flow direction of the glacier could be directly deduced by tectonical analysis. But this opinion is wrong! Glacigene deformations are caused by the load and the very local stresses of the glacier and are the result of movements within the sediments or en blocmovements of larger or smaller sedimentbodies, movements which are controlled by sev- eral different properties of the deformed materials.

Deformations studied in an exposure or section reveal the sum of all such movements. The structural analysis therefore in the first line determinates those internal movements. It is a second step to deduce the direction of a glacier's pressure and - that must be emphasized - a third step to draw then a conclusion on the direction of ice-flow.

\section{Examples for lateral pressing}

As the author's investigations in Schleswig-Holstein showed the deduction of the direction of ice-flow by glaciotectonical analysis is often very difficult, sometimes impossible, for there obviously exist deformations which don't strike transverse to the movement of a glacier. Studying glacigene deformations in an exposure it is in principle unknown how they strike in relation to the former ice-flow. Neglecting all less frequent possibilities one has in any case to take in consideration a strike parallel to the direction of ice-flow, which seems to be a relatively frequent deviation (cf. Stephan 1971). Although restricting movements in a sedimentary sequence which is overridden by a glacier more often follow shear 


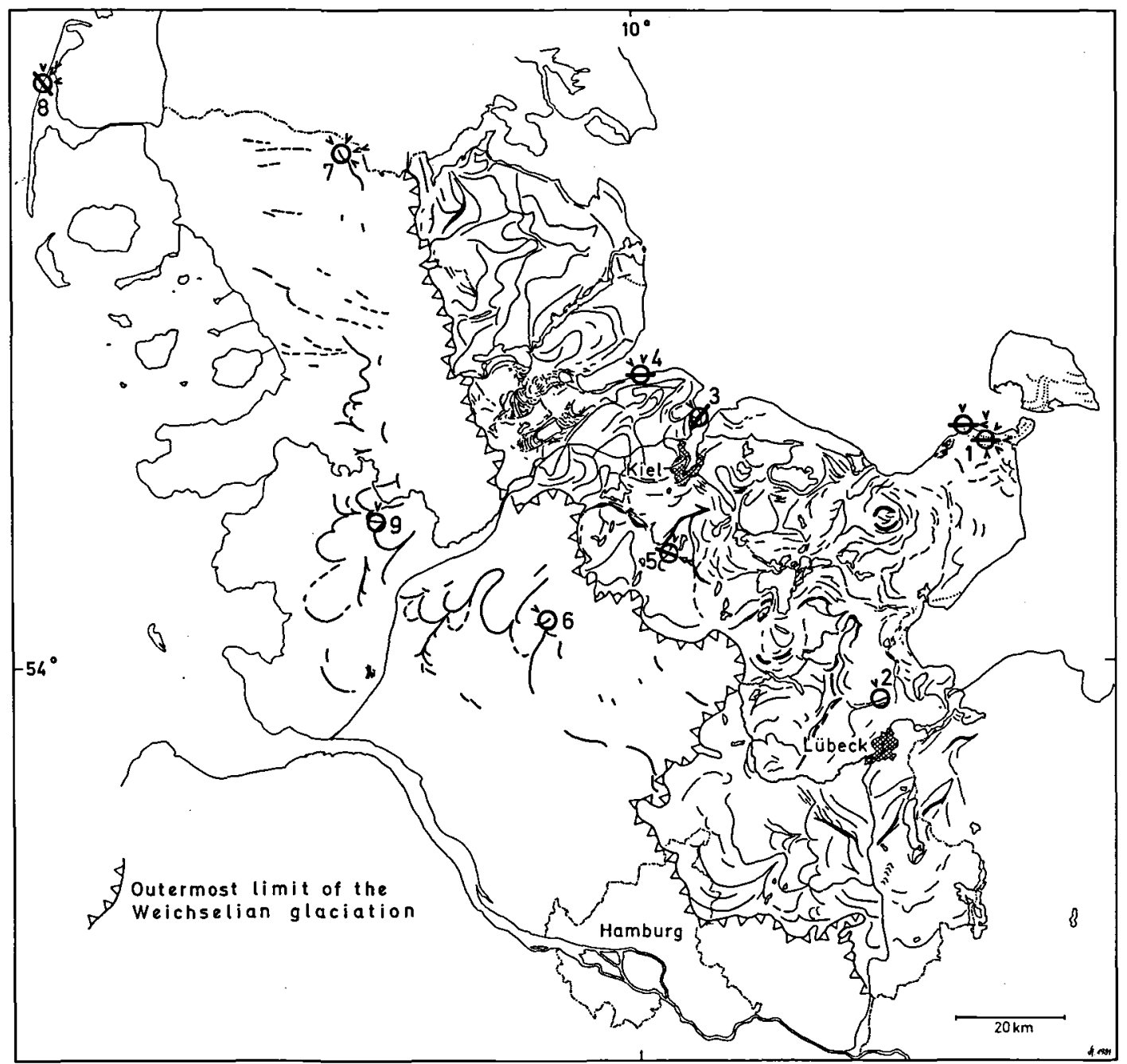

Fig. 1. Map of Schleswig-Holstein showing terminal ridges and the mentioned localities 1-9; arrows indicate the direction of push, strokes crossing the circles indicate the line of ice-flow.

stresses in the direction of glacier movement (down stream) than transverse to it in places transverse directed dislocations following normal stresses predominate.

In the following some examples from Schleswig-Holstein are described and shortly discussed:

Case a - pushing at the flanks of ice tongues

In fig. 1 the sites $2,3,4,6,8,9$ are examples for this very common type of lateral pressing. A few are described.
Site 2; Parinerberg: Between the large Weichselian ice lobe of the Lübeck basin and a smaller one in the north a ridge was pressed up. The internal structure shows strongly thrusting and often vertical standing units which strike parallel to the former ice-flow direction (ENE-WSW). The ridge can be called a compressed moraine.

Site 8; Sylt: On the island of Sylt glacial and preglacial sediments are exposed in the famous "Rotes Kliff". In the northern part the beds are thrusted. Measurements by Weinhold (in Stremme \& Menke 1980) and by the author prove an ice pressure from $E$ to $N$, mainly from 
ENE. Preliminary fabric analyses in the till cover show a preferred orientation of long axes of pebbles NW-SE to NNW-SSE. It coincides with the direction of striations on the polished surface of a boulder which lay beneath the till. A glacier-flow parallel to this line and a lateral pushing are very likely, although the direction of flow is unknown until now.

Site 9; Schalkholz: At the southern flank of the ice tongue basin of Schalkholz the Young Saalian glacier pushed and folded meltwater sediments. The fold axes strike ESE-WNW, approximately parallel to the former ice-flow.

The sites 3, 4, and 6 show similar conditions with lateral pushing at the flanks of ice tongues or lobes. Gripp (1979) discussed the occurrence of lateral thrusting for some other sites in Schleswig-Holstein ("laterale Press-Schuppen"), e.g. for the ridge of Heiligenhafen. His interpretation is only partly shared by the author (c.f. this article, case d).

Case $\mathrm{b}$ - block-movement:

Deformations striking parallel to the direction of ice-flow are also found in end moraines where frontal pushing directed downstream normally produces deformations striking transverse to the direction of ice-flow (Carlé, 1938).

Site 5; Brügge: About $20 \mathrm{~km}$ south of Kiel folded and thrust glacial sediments were exposed in a gravel pit. The structural analysis led to the assumption of a pushing from NNE which seemed to fit quite well with some morphological features in that area. Later on new exposures and their investigations showed that the first assumption was wrong. The ice advanced there during the second Weichselian advance towards WNW which was proved by fabric and structural analyses. Most of the later found deformations stroke NNE-SSW. In the first exposure had by chance been found a pushing transverse to the direction of ice-flow.

Site 7; Böxlund: A well studied exposure is the sand pit in the pushed ridge of Stolzberg near Böxlund. Fig. 2. shows all directions of compression (Einengung) which had been deduced by structural analyses by Weinhold (1980) and by the author. The main pressure obviously came from ENE from where the glacier is thought to have advanced. But there are some remarkable

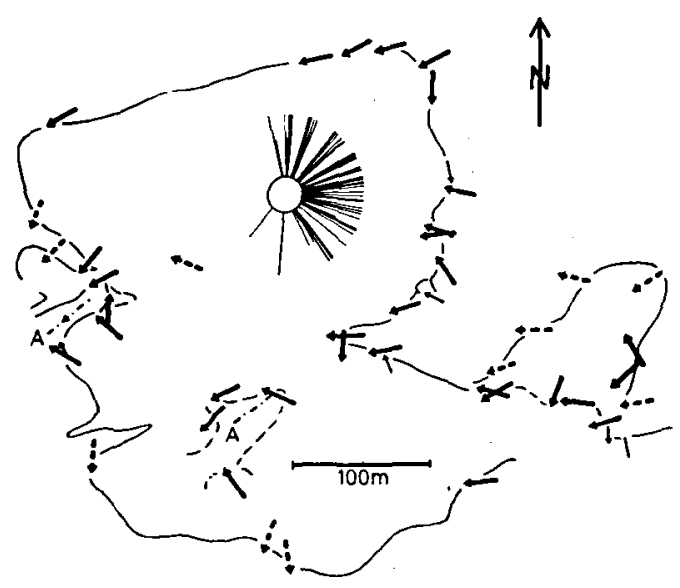

Fig. 2. The exposure of Böxlund; arrows indicate the direction of local dislocation and shortening; measurements by Stephan (solid) and by Weinhold (broken); all measurements are combined in the diagram. $A=$ axes of synclines with interglacial soils.

exceptions. In the western part of the pit deformations (synclines) occur which seem to have been caused by a push from SE. It is interesting to note, that the famous fossil soils of Böxlund had developed in these synclines striking transverse to the mass of deformations but approximately parallel to the movement of the pushing glacier.

Probably such deformations can be explained by a special movement of the glacier front which in German is called "Blockbewegung" (blockmovement). According to Pillewizer (1958; several older observations and publications are cited) in an advancing glacier with a strong activity there are separated portions moving over and beside another in blocks. This should especially happen when a flowing ice-mass is increasingly cramped by flanking slopes or ridges. Heerdt (1966) studied structures of a Weichselian (Pommerian) push-ridge in the north of Mecklenburg. He thought them to be caused by a block-movement of the glacier.

Fig 3 shows in which way within a push moraine the formation of structures striking parallel to the movement of a glacier could be explained by a block-movement.

Case $\mathrm{c}$ - subglacial deformations:

An important kind of deformations are those which developed subglacially. If the observations 


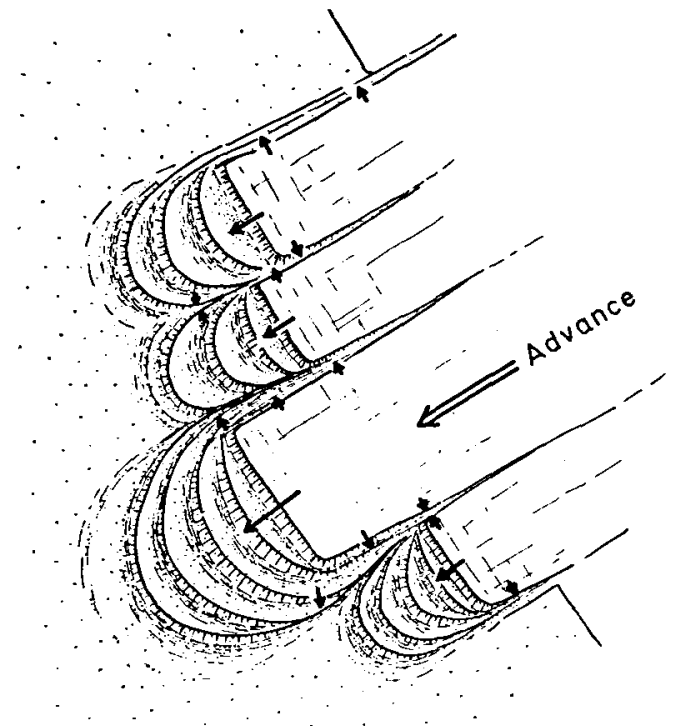

Fig. 3. Principle sketch "block-movement" of a glacier front. Proglacial thrust sheets (c.f. Köster 1957). Restricting movements within the sediments are frequently directed transverse to the direction of ice-flow (arrows).

during the author's field work in Schleswig-Holstein can be generalized, subglacially formed folds or thrusts mainly have minor dimensions, some millimetres up to eventually some metres in diameter, amplitude or extension. Axes of rotational structures and planes of restricting shearing movements seem to strike relatively frequent parallel to the ice movement. Ehlers \& Stephan (1979) described wedges and undulations which can be found in certain places at the lower surface of a till bed and interpreted them as being formed by restricting latitudinal shearing movements. As a rule they strike also parallel to the direction of the local ice movement.

One reason for subglacial deformations which strike parallel to the glacier movement can be that the glacier moves in differently active streams (observations and discussions e.g. by Philipp 1928, Asejew 1963: 15, Lawrushin 1971, Gripp 1975: 34, Chebotareva \& Faustova 1975: 253 with several citations, Aario 1977). If there are such differences within a glacier there must be also differences in accumulation or erosion and - partly only because of different ice load there must result movements within the subglacial sediments directed more or less transverse to the flow line. Especially along the hinges be- tween sectors with different velocities such movements can be assumed. These events can culminate in that phase where a still active ice tongue moves between stagnant ice fields. Ridges which have probably been formed in this way are found in the ground moraine plain of the glacial Lübeck basin. It is possible that the origin of such ridges is supported by injection-like mass flow from deeper horizons below the glacier into the ridges. In the Lübeck basin we find a typical sequence of till strata alternating with glaciolacustrine silt or clay strata. These materials could have been mobilized by the ice pressure. But until now we have no exposure in these ridges to prove this idea.

During the Younger Saalian and the Weichselian glaciation Schleswig-Holstein was situated in the outer zone of the inland ice and its landscape was repeatedly shaped by oscillations of the ice margin. Obstacles were more or less truncated by the younger advances. Sometimes the landscape as a whole was eroded. It is then called 'Exarationslandschaft' in German. Typical examples are the most eastern area of Holstein and the island of Fehmarn which were eroded by the Weichselian Fehmarn-advance. It can probably be correlated with the "Young Baltic"-advance, known from Denmark. In this eroded area lies the ridge of Heiligenhafen (fig. 1, site 1). It was pushed from NNE during an older Weichselian phase, probably the Pommerian stage. Later it was overridden by the Fehmarn-advance from $\mathrm{E}$ to $\mathrm{W}$. The limbs of the former arcuate ridge complex were cut down. The western limb is transected by the Heiligenhafen cliff. Investigations of its internal structures (Stephan, Kabel \& Schlüter 1982; Ehlers \& Stephan 1979: 350f.) showed that this limb is built up of a series of anticlinal folds which have been overridden and truncated by the Young Baltic glacier. At least at the eastern flanks of the easternmost folds shearing planes developed or had been reactivated during the young overriding which led to thrusting. All larger deformational structures strike about S-N, transverse to the young glacier movement: But superimposed on the thrust-bodies there have been found some smaller folds which strike approximately $\mathrm{E}-\mathrm{W}$ and thus absolutely parallel to the young ice-flow. In coincidence with the dip of the thrust bodies the axes of these folds often dip against $E$. On interpreting the cliff structures these E-W striking folds led to some confusion 


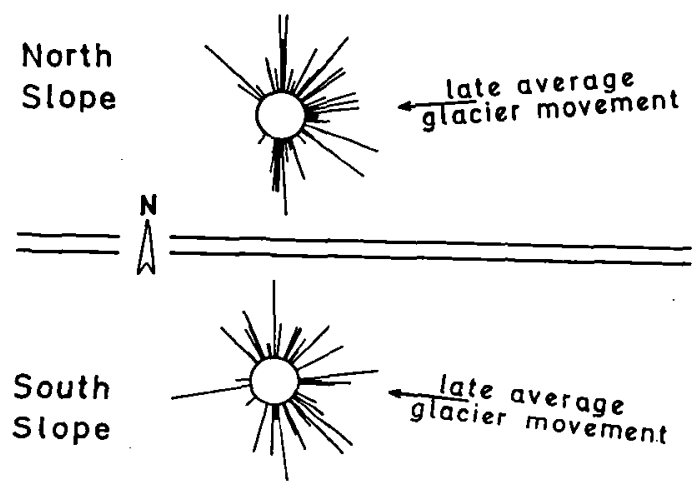

Fig. 4. Ridge of Heiligenhafen: "Seeming" directions of local dislocation (strikes directed against the circles).

for several times. The difficulties of interpretation are solved when these folds are explained as having been formed subglacially during the Young Baltic advance.
Case $d-a$ glacier flows around an obstacle:

When a young glacier advances into an older distinct relief the ice tries to flow around obstacles before they are overridden at last. The ridge of Heiligenhafen (fig. 1, site 1 , eastern circle) is an example for this. In spite of the overriding by the Young Baltic advance the middle part of the ridge outlasted because of its strike approximately parallel to the young glacier flow and perhaps because of its height and width. But it was drumlinized. Its surface is partly covered by' the young ground moraine. Many deformations in the sediments directly below this young till are the result of the last advance. In several exposures the deformations have been studied, and the deduced local "seeming" directions of shortening (Einengung) have been drawn together in two diagrams, one for the northern, one for the southern slope (fig. 4). The western sectors of both diagrams show very few directions. From

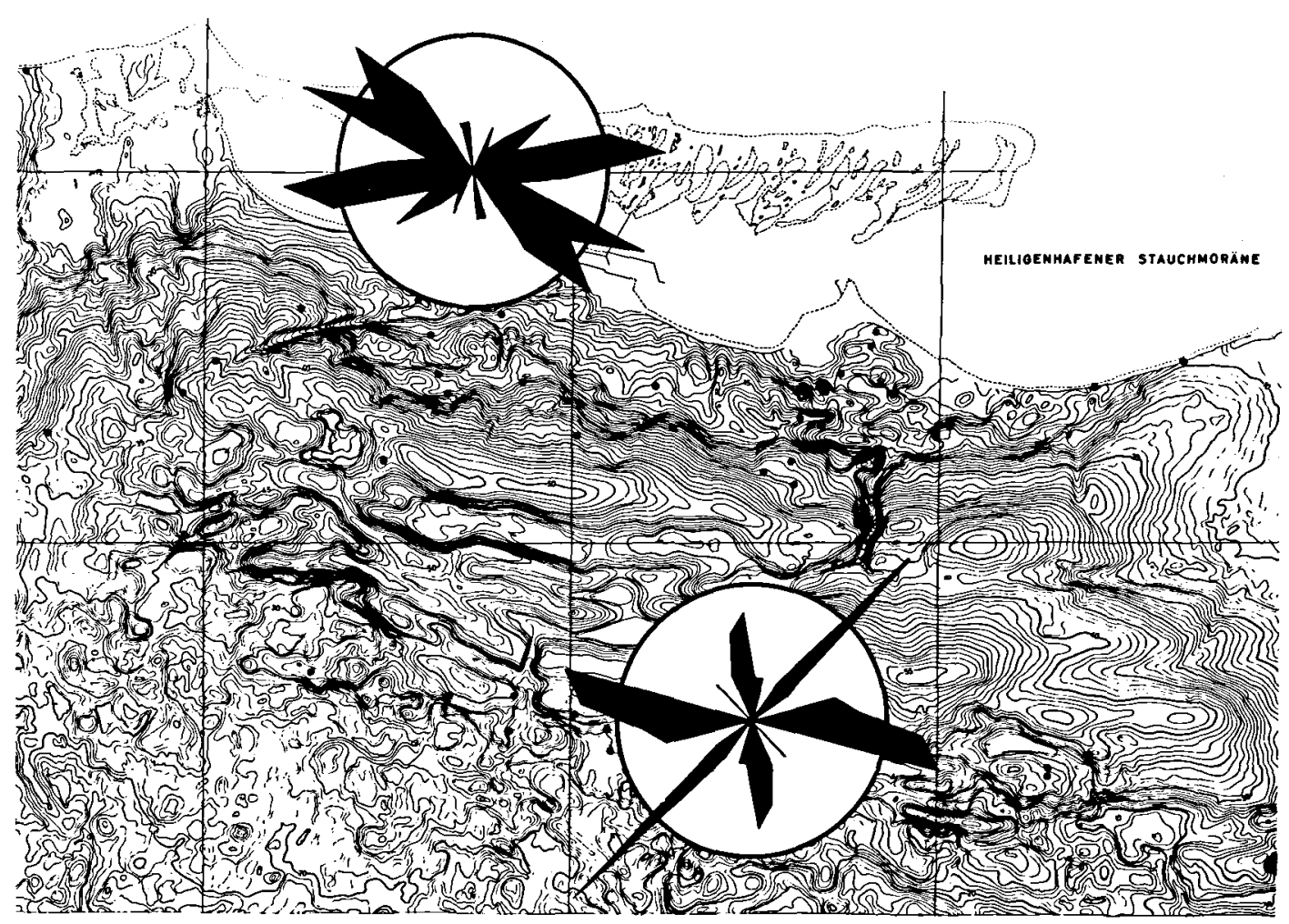

Fig. 5. Ridge of Heiligenhafen: Strike of large deformation structures combined in one diagram for the northern and in one diagram for the southern slope; black dots mark exposures. 
the opposite eastern sectors came the young advance. In fig. 5 only the strike of larger deformations (folds and thrust faults) are drawn into two diagrams, separated for the northern slope with 28 measurements and the southern slope with 31 measurements. Fig. 5 shows very clearly that we have 4 lines of strike forming approximately two cross-like systems: E-W/N-S and NE-SW/SE$\mathrm{NW}$. The $\mathrm{E}-\mathrm{W}$ lines in both diagrams coincide with the flow lines of the young glacier advance, diverging a little at the two slopes. The majority of all large deformations strikes parallel to this ice movement. Some of them - some large folds are the result of diapir-like mass movements of fine-grained materials which were mobilized by the glacier's pressure. (It is possible that these mass movements were supported by an oversaturation of water.)

The second system shows a clear NW-SE line at the northern slope, corresponding with a stress from NE which is assumed to be the resulting principle stress of a shear stress directed parallel to the ice-flow and a normal stress directed transverse to the ice-flow. At the southern slope an analogous resulting stress from SE caused deformations indicated by the distinct SW-NE line in fig. 5.

Deformations striking oblique to the direction of an ice advance have been found and studied also by Whittcar \& Mickelson (1981). They also explain them as formed by resulting principle stresses of glaciers flowing past an elongated ridge (drumlin) and over it. But it cannot be excluded that some of the oblique striking structures are the result of frontal pressing of the advancing glacier during the early phase with a lower ice-level (fig. 6). In the same way late oscillations during the general decay of the ice could have created similar deformations.

The investigations in the pits of the Heiligenhafen-ridge lead to the assumption that besides resulting principle stresses also the partial stresses created deformations. Especially the normal stresses of the passing glacier caused to a high extent structures striking parallel to the iceflow.

Another point in analysing the deformations of the ridge of Heiligenhafen is interesting: To all main maxima of strike in fig. 5 there exist transverse ones. The latter could become very distinct, when the lot of measurements of small fold

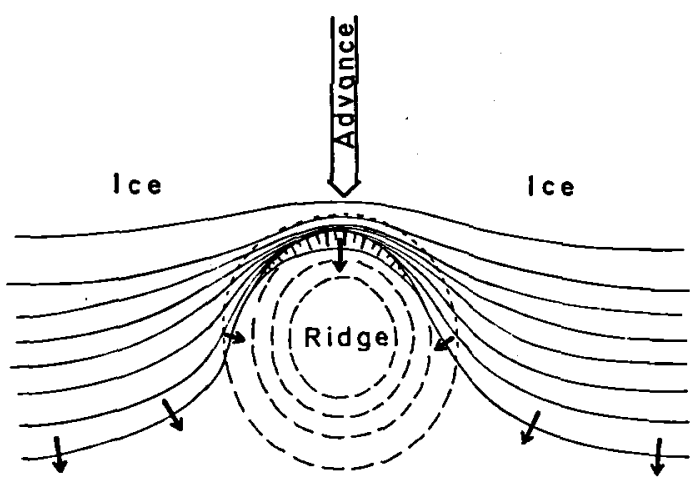

Fig. 6. Principle sketch showing a ridge flowed around by an advancing glacier (early phase); arrows mark the directions of local push.

axes would be added to the diagrams. But also some larger structures are striking transverse to the main directions, as indicated e.g. by the smaller NE-SW-maximum in the northern diagram of Fig. 5. The structural analysis showed that obviously the resulting principle stress created some strong transcurrent faults.

\section{Final considerations}

Together with the observations in the exposures the conclusion is allowed that many of the folds, thrusts and faults, especially the smaller ones, were formed at the edges of moved sediment bodies (slices, schollen). As we can assume that the edges of slices - statistically regarded - have a preferred strike approximately parallel to the direction of dislocation, deformations of a small scale are believed to strike also preferentially parallel to that direction. Dispersion occurs because of varying shape of the slices, differences or changing of the direction of dislocation, partly because of different transmission of the induced tensions by competent or incompetent beds or bodies, etc., but perhaps in the first place because many minor folds are so-called "dragged folds" (German: Schleppfalten) developed by differential shearing: When the bedding of a sediment is not horizontal, e.g. pushed or cross-bedded, the strike of the axes of such "dragged folds" is only controlled by the pre-existing strike of the bedding.

On principle the analysis of a glacigene de- 
formation only allows to deduce the direction of the local dislocation and perhaps of the local stress of a glacier, not directly the direction of its movement. Nevertheless - according to the experiences of field work - many measurements at many deformations, in several exposures of a certain region and their statistical analysis seem to give relatively practicable indications (c.f. figs. 2 and 4), on the understanding of course that all measured deformations belong to the same advance. In spite of this it is very important to use other methods in addition to check those indications.

\section{Dansk sammendrag}

Som så mange andre metoder, der anvendes til bestemmelse af tidligere isbevægelsesretninger, har også den glacialtektoniske metode sine begransninger. Ved en glacialtektonisk analyse kan man i princippet bestemme den lokale trykretning, men fejlfortolkninger opstår, når deformationsstrukturerne får strygninger, der er parallelle med hovedisbevægelsen, og de samtidig tolkes som strukturer, der er opstået ved en bevægelse vinkelret på strygningen.

Strukturer af denne type ses ofte i randmorænelandskaber udformet af fremskudte istunger, men de ses også $i$ bundmorænelandskaber, hvor deformationerne er opstået subglacialt.

I aldre landskabselementer, der senere er isoverskredet, og hvor retningen af bevægelsen styres af den eksisterende topografi, kan de aldre landskabsformer blive drumliniserede. I dette tilfalde ses det tit, at deformationsstrukturemes strygning er skæv $i$ forhold til den generelle isbevægelsesretning.

Strukturer kan også have strygninger, der er parallelle med isbevagelsesretningen. De antages at vare opstået som følge af stress forskelle ved isbasis mellem partier af ismasser, der bevægede sig med forskellig hastighed. Endvidere kan strukturer dannes ved diapiragtige materialeflytninger, hvor strygningen ofte kan være parallel med isbevægelsesretningen.

\section{References}

Aario, R. 1977: Associations of flutings, drumlins, hummocks, and transverse ridges. GeoJournal 1.6, 65-72.

Asejew, A. A. 1963: Die geomorphologische Zonalität des alten Eisgebietes der russischen Tafel; In: Report of the VIth internat. Congr. on Quaternary, Warsaw 1961, Vol. III, 9-20.

Carlé, W. 1938: Das innere Gefüge der Stauchendmoränen. Geol. Rdsch. 29, 27-51.

Chebotareva, N. S. \& Faustova, M. A. 1975: Struktur und Dynamik der letzten europäischen Eisbedeckung. Petermanns geogr. Mitt. 119(4), 253-260.

Ehlers, J. \& Stephan, H.-J. 1979: Forms at the base of till strata as indicators of glacier movement. Jour. Glaciology, Vol. 22 , No. $87,345-355$.

Gripp, K. 1975: 100 Jahre Untersuchungen über das Geschehen am Rande des europäischen Inlandeises. Eiszeitalter und Gegenwart 26, 31-73.

Gripp, K. 1979: Glazigene Press-Schuppen, frontal und lateral; In: Ch. Schlüchter (ed.) Moraines and Varves, 157-165; Rotterdam (A. A. Balkema).

Heerdt, S. 1966: Struktur und Entstehung der Stauchmoräne Kühlung. Geologie 15(10), 1169-1213.

Köster, R. 1957: Experimente zur glazialen Schuppung. N. Jb. Geol. u. Paläont. Mh. 1957, 510-517.

Lawruschin, J. A. 1971: Dynamische Fazies und Subfazies der Grundmoräne. Zeitschr. f. angewandte Geologie 17(8), 337-343.

Philipp, H. 1928: Neuere Beobachtungen zur Mechanik der Gletscher. A. Petermanns Mitt. 74, 7-12 u. 71-74.

Pillewizev, W. 1958: Neue Erkenntnisse über die Blockbewegung der Gletscher. Z. Gletscherkunde, Glazialgeologie, Bd. 4, H. 1-2, 23-33.

Stephan, H.-J. 1971: Glazialgeologische Untersuchungen im Raum Heiligenhafen (Ostholstein). Meyniana 21, 67-86.

Stephan, H.-J., Kabel, Ch. \& Schlüter, G. 1983: Stratigraphical problems in the glacial deposits of Schleswig-Holstein; In: J. Ehlers (ed.) Glacial deposits in North-West Europe, 305-320, fig. 314-325; Rotterdam (A. A. Balkema).

Stremme, H. E. \& Menke, B. (eds.) 1980: Quaternary excursions in Schleswig-Holstein, 102 pp.; Kiel (Geologisches Landesamt).

Weinhold, H. 1980: In: Stremme, H. E., Felix-Henningsen, P., Weinhold, H. \& Christensen, S. 1982: Merkmale und stratigraphische Bedeutung der Paläoböden des Quartärs in Schleswig-Holstein. Geol. Jb., F 14: 311-316.

Whittcar, G. R. \& Mickelson, D. M. 1979: Composition, internal structures, and an hypothesis of formation for drumlins, Waukesha County, Wisconsin, U.S.A. Jour. Glacialogy, Vol. 22, No. 87, 357-371. 